\title{
Long-Term Outcome of Soft Tissue Sarcomas of the Foot Treated with Limb Salvage Surgery and Radiotherapy
}

\author{
Didem C. OKSUZ ${ }^{1}$, Sefika A. ERGEN ${ }^{1}$, Sevim OZDEMIR ${ }^{1}$, Nuri KAYDIHAN ${ }^{1}$, Murat HIZ ${ }^{2}$, \\ Sedat KOCA ${ }^{2}$, Fazilet O. DINCBAS ${ }^{1}$ \\ ${ }^{1}$ Istanbul University, Cerrahpasa Faculty of Medicine, Department of Radiation Oncology \\ ${ }^{2}$ Istanbul University, Cerrahpasa Faculty of Medicine, Department of Orthopedic Surgery
}

Istanbul, TURKEY

\begin{abstract}
The objective of the present study was to review the long term follow up results of patients with primary soft tissue sarcomas (STS) of the foot who underwent limb sparing surgery with pre-or postoperative radiotherapy. Eleven patients with primary STS of the foot treated with limb sparing surgery and radiotherapy between 1980 and 2008 were retrospectively analyzed. The median tumor size was $5.5 \mathrm{~cm}(2-8 \mathrm{~cm})$. All patients were treated with limb sparing surgery. Surgical margin was positive in 5 patients. The most frequent histopathological diagnosis was synovial sarcoma (73\%). Radiotherapy was performed postoperatively to 8 patients and preoperatively to 3 patients. Six cases with high grade and large tumor received chemotherapy. The median follow-up period was 73 months (11 to 224 months). The 5-year overall survival was 78.8\%. Three patients developed local recurrence at median of 12 months (6-13 months). The histopathology of these patients was synovial sarcoma. The surgical margins were positive in one of them. One of the recurrent patients was salvaged by further limb sparing surgery and 2 patients required amputation. These 3 cases developed lung metastasis and 2 of them died due to metastatic disease. Eight patients without local recurrence remained disease-free at a median follow up of 73 months. Multidisciplinary approach is essential as in the other localizations, to get good oncologic and functional treatment outcomes in primary soft tissue sarcomas of the foot. Radiotherapy enables the limb preservation with good local control rate.
\end{abstract}

Keywords: Soft tissue sarcoma, Foot, Radiotherapy

ÖZET

Ekstremite Koruyucu Cerrahi ve Radyoterapi Uygulanan Ayak Yerleşimli Yumuşak Doku Sarkomlarında Uzun Dönem Takip Souçları

Bu çalışmanın amacı; primer ayak yerleşimli yumuşak doku sarkomu tanısıyla ekstremite koruyucu cerrahi ve preoperatif veya postoperatif radyoterapi uygulanan hastalarda uzun dönem takip sonuçlarının değerlendirilmesidir. 1980-2008 yılları arasında, ekstremite koruyucu cerrahi ve radyoterapi uygulanan primer ayak yerleşimli yumuşak doku sarkomlu 11 olgu retrospektif olarak değerlendirildi. Tümör boyutu medyan 5.5 cm'dir $(2-8 \mathrm{~cm})$. Tüm olgulara ekstremite koruyucu cerrahi yapıldı. Beş olguda cerrahi sınır pozitif saptandı. En sık görülen histolojik grup sinovyal sarkom'dur (73\%). Sekiz olguya postoperatif radyoterapi, 3 olguya preoperatif radyoterapi uygulandı. Yüksek grad ve büyük tümörü olan 6 olguya kemoterapi verildi. Medyan takip süresi 73 ay'dır (11-224 ay). 5 ylllık genel sağkalım \%78.8'dir. Üç olguda medyan 12 ayda (6-13 ay) lokal nüks gelişti. Nüks gelişen tüm olguların histopatolojisi sinovyal sarkomdu ve sadece bir olguda cerrahi sınır pozitifti. İki olguya nüks nedeniyle amputasyon yapılırken, diğer olguya tekrar ekstremite koruyucu cerrahi yapıldı. Lokal nüks gelişen bu üç olguda akciğer metastazı gelişti ve 2'si hastalıktan dolayı kaybedildi. Lokal nüksü olmayan 8 olgu medyan 73 ay takip süresi içerisinde hastalıksız olarak takip edilmektedir. Primer ayak yumuşak doku sarkomlarında iyi onkolojik ve fonksiyonel tedavi sonucu elde edebilmek için diğer bölge yumuşak doku sarkomlarında olduğu gibi multidisipliner yaklaşım oldukça önemlidir. Radyoterapi iyi lokal kontrol oranı ile ektremite korunmasına olanak sağlamaktadır.

Anahtar Kelimeler: Yumuşak doku sarkomu, Ayak, Radyoterapi 


\section{INTRODUCTION}

Soft tissue sarcomas (STS) are a heterogeneous group of rare malignancies representing less than $1 \%$ of adult malignancies and malignant foot STS account for approximately $2 \%$ to $5 \%$ of all cases. ${ }^{1,2}$ STS of the foot are frequently indolent and small, and early presentation of the symptoms are typical while there is limited area for the tumor expansion due to the anatomy of the foot..$^{3,4}$ The malignant potential of a tumor has often been underestimated since $70-84 \%$ of the soft tissue lesions of the foot are benign. ${ }^{5,6}$ This leads to unplanned excisions without proper imaging and staging. It has been shown that an unplanned excision or late diagnosis of malign STS has been correlated with worse outcome. ${ }^{7,8}$

The therapeutic approach and outcomes for this rare disease are not well established. The aim in the treatment of STS of the foot is maximizing local control and survival by means of the preservation of the optimal foot and joint function as well. However, for most of the patients limb sparing resection is not feasible due to the difficulty in achieving adequate margins, the lack of anatomic compartmentalization and the limitation of surgery for recurrence. ${ }^{9-12}$ Therefore, surgical management for foot STS is generally amputation while it is very difficult for patients and families to accept. Limb preservation management with combined surgery and radiotherapy is an alternative treatment approach to amputation. ${ }^{12-15}$ There has been few series focused on STS of the foot and evaluated the results of limb preservation surgery with radiotherapy. ${ }^{10,12,16-18}$

The objective of the present study was to review the long term follow up results of primary STS of the foot who underwent limb sparing surgery and preoperative or postoperative radiotherapy in our institute.

\section{PATIENTS AND METHODS}

We performed a retrospective review of 11 patients with primary STS of the foot treated with limb sparing surgery and preoperative or postoperative radiotherapy between 1980 and 2008, at a musculoskeletal tumor referral center. Patients with dermatofibrosarcoma protuberans, rhabdomyosarcoma, desmoid tumors and patients with distant metastases at the initial presentation were not included in the analysis. Our institutional board was informed before the analysis and the analysis was conducted in accordance with the principles of the Declaration of Helsinki and the rules of Good Clinical Practice. National rules do not require obtaining ethical committee approvals for retrospective studies.

All pathological diagnosis and evaluation of surgical margins were reviewed by our institutional musculoskeletal pathologists. Initial patient work-up included physical examination, routine blood counts, blood chemistry profile including renal and hepatic function tests, radiographs and magnetic resonance imaging of the distal lower extremity, chest radiography and/or chest computed tomography.

The tumor locations included dorsum of the foot in 8 cases and plantar aspect of the foot in 3 patients. The median tumor size was $5.5 \mathrm{~cm}$ (range 2 to $8 \mathrm{~cm}$ ). The most frequent histopathologic diagnosis was synovial sarcoma in 8 cases $(73 \%)$. The histopathologic differentiation of the tumors were reported as grade I in 1, grade II in 2 and grade III in 8 patients. The characteristics of the patients and tumors are summarized in Table 1. Five patients had wide local excision and 6 had marginal resection. Surgical margins were negative in 6 patients and positive in five. Soft-tissue coverage was performed with free flap soft-tissue transfer in 3 patients.

Patients with large, high grade tumors were more likely to receive preoperative radiotherapy. Adjuvant external beam radiation therapy was performed at least 3 weeks after resection, when surgical wound healing had existed. Patients were immobilized with an alpha cradle or a wooden box with rice. Five patients were treated with conventional 2D technique. Lateral or anteroposterior parallel-opposed or oblique fields were generally used. Six patients were irradiated with 3D conformal planning. The clinical target volume was created by giving a longitudinal margin of $3 \mathrm{~cm}$ and radial margin of $1.5 \mathrm{~cm}$ to the gross tumor volume or tumor bed if there is enough space. The size of the clinical target volume was determined individually according to the preoperative radiological data, surgical report, pathological data and the size of the scar. Surgical drain and incision sites were included within the initial treatment volume. In patients warranting postoperative radiotherapy, the treatment boost volume was constructed using a shrinking field technique after 


\begin{tabular}{|c|c|c|}
\hline Characteristics & Number of patients & $\%$ \\
\hline \multicolumn{3}{|l|}{ Gender } \\
\hline Female & 3 & 27 \\
\hline Male & 8 & 73 \\
\hline \multicolumn{3}{|l|}{ Tumor localization } \\
\hline Plantar & 3 & 27 \\
\hline Dorsal & 8 & 73 \\
\hline \multicolumn{3}{|l|}{ Surgery type } \\
\hline Marginal resection & 6 & 54 \\
\hline Wide local excision & 5 & 46 \\
\hline \multicolumn{3}{|l|}{ Surgical margin } \\
\hline Positive & 5 & 46 \\
\hline Negative & 6 & 54 \\
\hline \multicolumn{3}{|l|}{ Histopathologic subtype } \\
\hline Synovial sarcoma & 8 & 73 \\
\hline Pleomorphic sarcoma & 1 & 9 \\
\hline $\begin{array}{l}\text { Malignant peripheral nerve } \\
\text { sheath tumor }\end{array}$ & 1 & 9 \\
\hline Chondrosarcoma & 1 & 9 \\
\hline \multicolumn{3}{|l|}{ Radiotherapy } \\
\hline Preoperative & 3 & 27 \\
\hline Postoperative & 8 & 73 \\
\hline \multicolumn{3}{|l|}{ Chemotherapy } \\
\hline Preoperative & 2 & 18 \\
\hline Postoperative & 3 & 27 \\
\hline Concomitant & 1 & 9 \\
\hline
\end{tabular}

46-50 Gy. The boost volume was created by giving $2 \mathrm{~cm}$ margin in longitudinal plane and $1.5 \mathrm{~cm}$ radially to tumor bed. Irradiation of the entire circumference of the foot was avoided, a strip of normal tissue was spared along the length of the foot, and the ankle joint, achilles tendon were not included in the high dose volume whenever possible. We used rice or paraffin bolus on the surgical scar to build up skin dose when needed.

Radiotherapy was delivered with Co60 machine or 4-6 MV linear accelerators. Radiotherapy was implemented preoperatively to 3 patients with a dose of $46 \mathrm{~Gy}$ in 23 fractions over 4.5 weeks and postoperatively to 8 patients with a dose of 60-66 Gy in 30-33 fractions over 6-6.5 weeks. One patient with positive surgical margin treated with brachytherapy to a dose of $13.5 \mathrm{~Gy}$ in 7 fractions in addition to preoperative external beam radiotherapy. Six cases $(54.5 \%)$ with high grade and large tumor received chemotherapy consisting of doxorubicin $75 \mathrm{mg} / \mathrm{m}^{2}$ on D1, ifosfamide with mesna $2 \mathrm{~g} / \mathrm{m}^{2}$ on D1-3 every3 weeks. Treatment details can be seen in Table 1 .

All patients were followed by physical examination, every 3 months until 2 years after surgery and every 6 months up to the fifth year. Magnetic resonance imaging of the primary site and thorax computed tomography and serum chemistry panel were repeated every 6-12 months. Further investigations were performed only when clinically indicated. Survival analysis was performed using the Kaplan-Meier method using the time of initiation of treatment as the starting point. Long-rank tests were used to assess for significance of differences between curves.

\section{RESULTS}

There were 8 male and 3 female patients with a median age of 42 years (range, 26 to 71). Two patients had been operated elsewhere previously and referred us after local recurrence. Nine patients did not receive any treatment before. The median follow-up period was 73 months (range, 11 to 224). Three of 11 patients developed local recurrence at median of 12 (range, 6 to 13) months, resulting in a 5 -year local control rate of $71 \%$.

The first patient who had a local recurrence was treated with chemoradiotherapy after the marginal resection of tumor. He had an infield recurrence 12 months after therapy. Despite subsequent salvage below knee amputation, lung metastasis was observed in 20th months of follow-up. He was treated with chemotherapy. But, he died due to the progression of lung metastases. Second patient had been referred to our clinic due to recurrent sarcoma following the unplanned excision. The marginal excision of the tumor located on the dorsum of the foot and adjuvant radiochemotherapy were performed. He had an outfield recurrence after 6 months. The new lesion was on the plantar aspect of the foot and treated with salvage surgery with postoperative radiotherapy and chemotherapy. But, 19 months later he had another local recurrence and amputation below the knee was performed. Unfortunately, he experienced local recurrence in the stump and the lung metastasis in 57th month of follow up. Amputation 


\begin{tabular}{|c|c|c|c|}
\hline & Case 1 & Case 2 & Case 3 \\
\hline Age & 57 & 30 & 38 \\
\hline Histology & Synovial & Synovial & Synovial \\
\hline Primer Surgery & Marginal resection & Wide local excision & Marginal resection \\
\hline Surgical margin & $(-)$ & $(-)$ & $(+)$ \\
\hline Chemotherapy & $(+)$ & $(+)$ & $(-)$ \\
\hline Radiotherapy dose & 64 Gy & 64 Gy & 66 Gy \\
\hline Local recurrence location & In treatment field & Out of treatment field & Out of treatment field \\
\hline Local recurrence time (month) & 12 & $6 / 25 / 57 / 72$ & 13 \\
\hline Treatment of local recurrence & Amputation & $\begin{array}{l}\text { 1st recurrence: Wide local } \\
\text { excision+postoperative } \\
\text { radiotherapy\&chemotherapy } \\
\text { 2nd recurrence:Amputation } \\
\text { below knee } \\
\text { 3rd recurrence: Amputation } \\
\text { above knee + Chemotherapy } \\
\text { 4th recurrence: Radiotherapy }\end{array}$ & Limp sparing surgery \\
\hline Lung metastasis (month) & 20 & 57 & 30 \\
\hline Outcome & Died of disease & Alive with disease & Died of disease \\
\hline
\end{tabular}

above the knee was performed. Fifteen months later, he developed a new recurrence in his stump that has been controlled with radiotherapy. Now, he is alive with disease during a follow-up 79 months and he is receiving chemotherapy. The third case was referred to our clinic after marginal resection with positive surgical margin. He had an out of field relapse in the soft tissue of the right tibia and inguinal lymph node metastases, 13 months after postoperative radiotherapy. He underwent a limb sparing surgery. Eventually, he had a lung metastasis in 30th month and died of his disease despite the chemotherapy. The details of the patients with recurrence can be seen in Table 2.

The overall 5-year survival rate of all patients was $78.8 \%$. Out of the 11 patients in the cohort, 1 patient was alive with disease and 2 patients died of their disease at the time of evaluation. Eight $(72.7 \%)$ patients without local recurrence remained diseasefree at a median follow-up of 73 months.

On univariate analysis tumor size, histopathologic subtype, surgical margin status, type of surgery did not significantly affect local control, disease-free and overall survival rates. The 5-year disease-free survival and overall survival rates were significantly worse for patients with local recurrence, respectively $(\mathrm{p}=0.001$ and $\mathrm{p}=0.021)$. Table 3 shows the results of univariate analysis of prognostic factors that might influence 5-year local control, diseasefree and overall survival rates. Multivariate analysis has not been performed in the current study due to the small number of patients.

Hyperpigmentation and wet desquamation were the most commonly seen acute toxicity during the radiotherapy. Two patients whose tumor was located in plantar region required treatment interruption due to acute skin reaction. Three patients had delayed wound healing. One patient experienced postoperative wound infection, and this patient was required amputation of toe. Two patients had chronic edema and four patients had fibrosis that cause decrease range of motion. The patients without local recurrence were ambulatory with or without external support, and they were satisfied with the foot function. 


\begin{tabular}{|c|c|c|c|c|c|c|c|}
\hline & \multirow[b]{2}{*}{$\mathbf{N}$} & \multicolumn{2}{|c|}{ Local Control } & \multicolumn{2}{|c|}{ Disease Free Survival } & \multicolumn{2}{|c|}{ Overall Survival } \\
\hline & & 5 years $(\%)$ & $\mathbf{P}$ & 5 years $(\%)$ & $\mathbf{p}$ & 5 years $(\%)$ & p \\
\hline \multicolumn{8}{|l|}{ Tumor size } \\
\hline$\leq 5 \mathrm{~cm}$ & 5 & 80 & 0.84 & 80 & 0.84 & 100 & 0.26 \\
\hline$>5 \mathrm{~cm}$ & 6 & 67 & & 67 & & 67 & \\
\hline \multicolumn{8}{|c|}{ Histopathologic subtype } \\
\hline Synovial sarcoma & 8 & 63 & 0.31 & 63 & 0.31 & 72 & 0.44 \\
\hline Others & 3 & 100 & & 100 & & 100 & \\
\hline \multicolumn{8}{|c|}{ Resection margin status } \\
\hline Negative & 6 & 80 & 0.46 & 80 & 0.46 & 80 & 0.72 \\
\hline Positive & 5 & 63 & & 63 & & 75 & \\
\hline \multicolumn{8}{|l|}{ Surgery type } \\
\hline Marginal resection & 6 & 60 & 0.64 & 60 & 0.64 & 60 & 0.15 \\
\hline Wide local excision & 5 & 80 & & 80 & & 100 & \\
\hline \multicolumn{8}{|l|}{ Local recurrence } \\
\hline$(+)$ & 3 & & & 0 & 0.001 & 33 & 0.021 \\
\hline$(-)$ & 8 & & & 100 & & 100 & \\
\hline
\end{tabular}

\section{DISCUSSION}

The management and outcomes of primary STS of the foot have not been extensively studied while STS of foot were usually reported together with the bone sarcomas, metastatic tumors or benign tumors and STS of the hands or ankle in the analysis. ${ }^{1,67,714,15,19,20}$ Additionally, few reports did not describe the oncologic outcomes of STS of the foot. ${ }^{6}$ So, it is difficult to compare the studies and describe the prognostic factors and to get optimal therapeutic approach. General principles of limb sparing treatment approach for extremity sarcomas can be adapted to the foot STS. Functional limb conservation may maintain physical, psychological, and social benefits. ${ }^{9,12,13}$ However, it is difficult to obtain wide resection margins for the foot tumors which increase the risk of both local recurrence and distant metastases. In addition to this, irradiation of the foot is challenging especially due to poor radiation tolerance of the skin of the sole. It is also difficult to manage local recurrences with re-resection with wide margins for limb preservation. Therefore, the amputation is applied more for the foot STS other than the STS of the extremities.
According to the treatment protocol of our institution, radiotherapy has been performed to patients with close or positive margins, high grade and/or inoperable for limb sparing surgery due to the advanced tumor or who did not accepted amputation. Radiotherapy can control the residual microscopic disease, and the local recurrence rate has been reported to be below $10 \%$ when combined with postoperative radiotherapy. ${ }^{13,14,21}$ Good local control with sparing of limb function using the combined therapeutic approach in the sarcoma of foot has been demonstrated. . $, 8,10,22^{2}$

In the literature, local recurrence rate was $10-14 \%$ for STS of the foot. ${ }^{7,11,13}$ Temple et al and Kozawa et al. reported worse outcomes in patients undergoing amputations compared to patients having limb sparing surgery. ${ }^{11,23}$ However, the other studies did not show any significant difference. Salipas et al. analyzed 33 patients with primary STS of the foot and ankle and $19(42.4 \%)$ of the patients were treated by amputation while only 2 of them had a local recurrence. ${ }^{24}$ Azevedo et al. reported high amputation rate (44\%) with good local control and only 4 out of 15 STS patients received radiotherapy in this study. ${ }^{20}$ Latt et al. reviewed the 16 patients with 


\begin{tabular}{|c|c|c|c|c|c|}
\hline Authors & $\begin{array}{l}\text { Total number } \\
\text { of patients }\end{array}$ & $\begin{array}{l}\text { Number of patients } \\
\text { with STS of the foot }\end{array}$ & $\begin{array}{l}\text { Local } \\
\text { recurrence }\end{array}$ & $\begin{array}{l}\text { Distant } \\
\text { metastasis }\end{array}$ & Amputation \\
\hline Talbert, et al. ${ }^{12}$ & $\begin{array}{c}78 \text { (hand, wrist, } \\
\text { foot, ankle) }\end{array}$ & 22 & 5 & 4 & 12 \\
\hline Jyothirmayi, et al. ${ }^{10}$ & 41 (hand \& foot) & 23 & 9 & 10 & 2 \\
\hline Cassidy, et al. ${ }^{18}$ & $\begin{array}{c}33 \text { (hand, wrist, } \\
\text { foot, ankle) }\end{array}$ & 15 (foot\&ankle) & 1 & 3 & - \\
\hline Schoenfeld, et al. ${ }^{17}$ & 23 (hand \& foot) & 11 & - & 2 & - \\
\hline Bishop AJ, et al. ${ }^{16}$ & 85 (hand \&foot) & 47 & $\begin{array}{l}\text { 5-year } \\
\text { LC: } 86 \%\end{array}$ & $\begin{array}{l}\text { 5-year } \\
\text { DMFS: } 85 \%\end{array}$ & 5 (hand\&foot) \\
\hline Present study & 11 & 11 & 3 & 3 & 2 \\
\hline
\end{tabular}

STS of the foot and noted $19 \%$ amputation rate. ${ }^{8}$ Limb salvage surgery with pre-or postoperative radiotherapy was used in $70 \%$ of the patients, leading to a local recurrence rate of $15 \%$ with acceptable foot function. ${ }^{8}$ Ozger et al. reported 16 cases of malignant tumors of the foot and ankle and 9 of them were STS of the foot. Limb salvage surgery with pre or postoperative radiotherapy was performed to 6 patients and distant metastasis was detected in one patient after a mean 74.2 months of follow-up. ${ }^{15}$

The studies that evaluated the long-term outcomes of patients treated with limb sparing surgery and radiotherapy for STS of the foot demonstrated an excellent rates of local control and survival with good functional outcome (Table 4). ${ }^{16-18}$ However, in Jyothirmayi et al.'s series local relapse-free survival was high as $44 \%$, compared to other studies. ${ }^{10}$ The reason might be the high proportion of recurrent tumors in their series. This suggests the need for routine postoperative radiotherapy after the initial conservative surgery for foot sarcoma. Furthermore, they noted that most of the recurrences were within the volume suggesting the necessity of higher total doses of radiotherapy ( $>60 \mathrm{~Gy}$ ) especially in patients with positive margins.

In the present study 5-year local control rate was modestly lower than the recent series. It might be due to the fact that most of our patients had unfavorable characteristics such as tumor size were $\geq 5 \mathrm{~cm}$ in $64 \%$ cases and $73 \%$ of patients had high grade tumors. Nevertheless, we preserved the extremities of our patients at the first face and one of the 3 patients with local recurrence was salvaged by further limb sparing surgery. Besides, two out of three patients with a local relapse that was controlled with salvage treatments, died due to lung metastases. Overall systemic recurrence rate was $27.2 \%$ at a median time of 30 months. The 5-year survival rate of $78.8 \%$ in the present study was comparable with other studies. ${ }^{5,7,11,12}$

Few studies have analyzed the prognostic factors for foot sarcoma. Talbert et al. demonstrated that the larger tumor size was associated with worse disease free survival. ${ }^{12}$ It has been reported that unplanned excisions worsen the outcome and complicate the limb salvage treatment. ${ }^{78}$ Local recurrence rate was reported to be higher in the patients with positive surgical margins compared to the patients with negative margins in the series of Kozawa et al..$^{23}$ One of the largest series evaluating limb conserving surgery and radiotherapy in 85 patients with STS of foot and hand demonstrated that positive surgical margin status was adversely associated with local recurrence. But, this lost significance on multivariate analysis when adjusting for radiotherapy dose more than $64 \mathrm{~Gy}{ }^{16}$

In the present study, patients who had a local relapse had significantly worse disease-free survival 
and overall survival rates, similar to Bishop et al. study. ${ }^{16}$ However, we couldn't observe the significant effect of positive surgical resection margins and local recurrence was observed in only one out of the 5 patients with microscopically positive resection margin. This might be due to the effect of the high dose radiotherapy applied in our patients with positive surgical margin as Bishop et al. stated. ${ }^{16}$ In our study the common feature of the patients with recurrence was histopathology. The histopathology of all recurrent tumor was synovial sarcoma. Synovial sarcomas were reported to be the most frequent malignant histological type among the STS of the foot. ${ }^{6,7,9,15,20,23-26}$ Synovial sarcoma has poor prognosis due to the patterns of recurrence such as local invasion potential along the fascia, regional lymph node metastases and the distant metastases. ${ }^{22}$ In this study, even though there is a distinct difference of local control, disease-free and overall survival rates between patients with synovial histopathology and the patients with other histopathology, this difference was not statistically significant. Our patients with local recurrences were controlled with salvage treatments. But, 2 patients with this aggressive tumor pathology died due to metastasis. So, inherent tumor biology rather than the other factors may be more essential for metastases and more aggressive chemotherapy regimens are needed.

There are some limitations of this study. Firstly, this study is a retrospective review and is therefore susceptible to the limitations and biases of all retrospective studies. Secondly, although oncologic outcomes may be compromised with large size, surgical margin status, type of surgery, histopathologic subtype, it did not reach to a statistical significance due to the small number of patients that is mostly attributed to the rarity of primary STS of the foot. Beside these limitations, the present study is a homogenous series of patients with primary STS of foot from single institution. Dermatofibrosarcoma protuberans, rhabdomyosarcoma, desmoid tumors, Ewing sarcoma, osteosarcoma that were included in other studies were excluded in our study. Also, our study focused exclusively on long term outcomes of extremity sparing treatment approach for the patients with primary STS of foot, treated with pre-orpostoperative radiotherapy, that gives a chance for preserving the foot.
In conclusion, amputation is still the most commonly used treatment option for the foot STS. However the physiological and social effects cannot be ignored and some of the patients do not accept such a radical surgery. Although the anatomy of the foot limits wide excisions radiotherapy may improve the local control rates in this situation and enables the limb preservation. Therefore, an experienced multidisciplinary evaluation and treatment combinations are needed as in other regional STS to get good oncologic and functional treatment outcomes in STS of the foot.

\section{Acknowledgements}

This study was presented in part at the 28th Annual Meeting of the European Musculo-Skeletal Oncology Society, Athens, Greece, April 29th-May 1st, 2015.

\section{REFERENCES}

1. Chou LB, Ho YY, Malawer MM. Tumors of the foot and ankle: experience with 153 cases. Foot Ankle Int 30: 836-841, 2009.

2. Bakotik BW, Borkowski P. Primary soft-tissue neoplasms of the foot: the clinicopathologic features of 401 cases. J Foot Ankle Surg 40: 28-35, 2001.

3. Kirby EJ, Shereff MJ, Lewis MM. Soft-tissue tumors and tumor like lesions of the foot. An analysis of eighty-three cases. J Bone Joint Surg Am. 71: 621-626, 1989.

4. Walling AK, Gasser SI. Soft-tissue and bone tumors about the foot and ankle. Clin Sports Med. 13: 909-38, 1994.

5. Zeytoonjian T, Mankin HJ, Gebhardt MC, Hornicek FJ. Distal lower extremity sarcomas: frequency of occurrence and patient survival rate. Foot Ankle Int 25: 325-330, 2004

6. Ruggieri P, Angelini A, Jorge FD, et al. Review of foot tumors seen in a university tumor institute. J Foot Ankle Surg 53: 282-285, 2014.

7. Thacker MM, Potter BK, Pitcher JD, Temple HT. Soft tissue sarcomas of the foot and ankle: impact of unplanned excision, limb salvage, and multimodality therapy. Foot Ankle Int 29: 690-698, 2008.

8. Latt LD, Turcotte RE, Isler MH, Wong C. Case series. Soft tissue sarcoma of the foot. Can J Surg 53: 424-431, 2010.

9. Chou LB, Malawer MM. Analysis of surgical treatment of 33 foot and ankle tumors. Foot Ankle Int 15: 175-181, 1994.

10. Jyothirmayi R, Sittampalam $Y$, Harmer C. Soft tissue sarcoma of the hand or foot: conservative surgery and radiotherapy. Sarcoma 3: 17-24, 1999. 
11. Temple, HT, Worman DS, Mnaymneh WA. Unplanned surgical excision of tumors of the foot and ankle. Cancer Control 8: 262-268, 2001

12. Talbert ML, Zagars GK, Sherman NE, Romsdahl MM. Conservative surgery and radiation therapy for soft tissue sarcomas wrist, hand, ankle and foot. Cancer 66: 2482-2491, 1990.

13. Selch MT, Kopald KH, Ferreiro GA, et al. Limb salvage therapy for soft issue sarcomas of the foot. Int J Radiat Oncol Biol Phys 19: 41-48, 1990.

14. Colterjohn NR, Davis AM, O'Sullivan B, et al. Functional outcome in limb-salvage surgery for soft tissue tumors of the foot and ankle. Sarcoma 1: 67-74, 1997.

15. Ozger H, Eralp L, Turker M, Basaran M. Surgical treatment of malignant tumors of the foot and ankle. Int $\mathrm{J}$ Clin Oncol 10: 127-132, 2005

16. Bishop AJ, Zagars GK, Moon BS, et al. Combined LimbSparing Surgery and Radiation Therapy to Treat Sarcomas of the Hands and Feet: Long-Term Cancer Outcomes and Morbidity. Int J Radiat Oncol Biol Phys 92: 1060-1068, 2015.

17. Schoenfeld GS, Morris CG, Scarborough MT, et al. Adjuvant radiotherapy in the management of soft tissue sarcoma involving the distal extremities. Am J Clin Oncol 29: 62-65, 2006.

18. Cassidy RJ, Indelicato DJ, Gibbs CP, et al. Function preservation after conservative resection and radiotherapy for softtissue sarcoma of the distal extremity: Utility and application of the Toronto extremity salvage score (TESS). Am J Clin Oncol 2014. Doi: 10.1097/COC.0000000000000107

19. Ozdemir HM, Yildiz Y, Yilmaz C, Saglik Y. Tumors of the foot and ankle: analysis of 196 cases. J Foot Ankle Surg 36: 403408, 1997.

20. Azevedo C, Casanova JM, Guerra MG, et al. Tumors of the foot and ankle: A single-institution experience. J Foot Ankle Surg 52: 147-152, 2013
21. Davis AM, O'Sullivan B, Turcotte R, et al. Canadian Sarcoma Group, NCl Canada Clinical Trial Group Randomized Trial. Late radiation morbidity following randomization to preoperative versus postoperative radiotherapy in extremity soft tissue sarcoma. Radiother Oncol 75: 48-53, 2005.

22. Sobel E, Giorgini R, Oropeza R, et al. Limb salvage in recurrent synovial sarcoma of the right ankle and lower leg. J Am Podiatr Med. Assoc 92: 90-96, 2002.

23. Kozawa E, Nishida $\mathrm{Y}$, Nakashima $\mathrm{H}$ et al. Foot sarcomas: factors affecting oncological and functional outcomes. Oncol Lett 3: 82-88, 2012.

24. Salipas A, Dowsey MM, May D, Choong PFM. Beware the lump in the foot!: predictors of recurrence and survival in bone and soft tissue sarcomas of the foot and ankle. AZN J Surg 84: 533-538, 2014.

25. Scully SP, Temple HT, Harrelson JM. Synovial sarcoma of the foot and ankle. Clin Orthop Relat Res 364: 220-226, 1999.

26. Cribb GL, Loo SCS, Dickinson I. Limb salvage for soft-tissue sarcomas of the foot and ankle. J Bone Joint Surg 92: 424429, 2010

\section{Correspondence}

Dr. Didem Çolpan ÖKSÜZ

İstanbul Universitesi Cerrahpaşa Tıp Fakültesi

Radyasyon Onkolojisi Anabilim Dalı

Fatih

ISTANBUL / TURKEY

Tel: (+90-212) 4143098

Fax: (+90-212) 4143101

e-mail: dcolpanoksuz@gmail.com 